\title{
MENINGKATKAN KEMAMPUAN KOSAKATA BAHASA DAYAK DESA MELALUI MEDIA FLASHCARD PADA ANAK USIA DINI
}

\author{
Fransiska \\ Program Studi Pendidikan Guru Pendidikan Anak usia Dini \\ STKIP Persada Khatulistiwa Sintang Kalimantan Barat \\ email: fransiskastg@gmail.com
}

\begin{abstract}
Abstrak
Penelitian ini bertujuan untuk meningkatkan kemampuan kosakata bahasa Dayak Desa melalui media flashcard pada siswa kelompok B (5-6 tahun) di TK Buah Rindang Desa Umin Jaya Kecamatan Dedai Kabupaten Sintang. Bentuk penelitian ini menggunakan desain Penelitian Tindakan Kelas (PTK) yang terdiri dari dua sikus. Penelitian dilaksanakan pada 17 siswa kelompok B (5-6 tahun) di TK Buah Rindang Desa Umin Jaya Kecamatan Dedai Kabupaten Sintang. Teknik pengumpulan data menggunakan teknik observasi, wawancara, tes dan dokumentasi. Hasil penelitian menunjukkan bahwa rata-rata kemampuan kosakata bahasa Dayak Desa pada siklus I sebesar $65,43 \%$. Hal ini membuktikan bahwa kemampuan kosakata bahasa Dayak Desa dengan menggunakan media flashcard belum meningkat secara optimal. Sedangkan pada siklus II anak mengalami peningkatan yang signifikan dengan hasil sebesar $84,18 \%$. Peningkatan dari siklus I ke siklus II terjadi sebesar $18,75 \%$. Berdasarkan hasil penelitian tersebut maka dapat ditarik kesimpulan bahwa media flashcard dapat meningkatkan kemampuan kosakata bahasa Dayak Desa pada siswa kelompk B (5-6 tahun) di TK Buah Rindang Desa Umin Jaya Kecamatan Dedai Kabupaten Sintang.
\end{abstract}

Kata Kunci : Kosakata Bahasa Dayak Desa, Flashcard, Taman Kanak-Kanak

\begin{abstract}
This study aims to improve the vocabulary skills of Dayak Desa language through flashcard media in group B students (5-6 years) in Buah Rindang Kindergarten, Desa Umin Jaya, Dedai District, Sintang Regency. This study applies a Classroom Action Research $(C A R)$ design consisting of two cycles. The study was conducted on 17 students in group $B$ (5-6 years) in Buah Rindang Kindergarten at Desa umin Jaya, Dedai District, Sintang Regency. Data collection techniques are observation, interview, test and documentation techniques. The result showed that the average ability of the vocabulary skills of Dayak Desa language in the first cycle was $65.43 \%$. This proves that the ability of the vocabulary skills of Dayak Desa language using flashcard media has not increased optimally. While in the second cycle the students' ability experienced a significant increase with a result of $84.18 \%$. The increase from cycle I to cycle II is $18.75 \%$. Based on the result of the study, it can be concluded that the flashcard media can improve the students' vocabulary skills of Dayak Desa language in group B students (5-6 years) in Buah Rindang Kindergarten, Desa Umin Jaya, Dedai District, Sintang Regency
\end{abstract}

Keywords: Dayak Desa Language Vocabulary, Flashcard, Kindergarten 


\section{PENDAHULUAN}

Pendidikan merupakan hal yang penting bagi semua orang, baik itu dari anak-anak sampai orang dewasa. Melalui pendidikan orang akan memperoleh pengetahuan bagi dirinya. Begitu pula pada anak usia dini pendidikan penting dalam menunjang perkembangan mereka dalam kehidupan sehari-hari. Pendidikan anak usia dini adalah pendidikan yang diberikan pada anak yang berusia dari 0-6 tahun yang dikenal sebagai masa keemasan (the golden age). Menurut Undang-Undang nomor 20 Tahun 2003 tentang sistem pendidikan nasional menyebutkan bahwa pendidikan anak usia dini (PAUD) adalah suatu upaya pembinaan yang ditujukan kepada anak sejak lahir sampai dengan usia enam tahun yang ditujukan melalui pemberian ransangan pendidikan untuk membantu pertumbuhan dan perkembangan jasmani dan rohani agar anak memiliki kesiapan dalam memasuki pendidikan lebih lanjut. Di dalam pendidikan anak usai dini ada 6 (enam) aspek yang harus dikembangkan supaya pendidikan pada anak usia dini tersebut menjadi optimal. Keenam aspek tersebut meliputi agama dan moral, fisik motorik, kognitif, sosial emosional, bahasa, seni.

Salah satu aspek yang penting dikembangkan pada anak adalah bahasa. Bahasa pertama kali diperoleh anak melalui keluarga karena keluarga merupakan pendidikan pertama bagi anak dan dalam jalur pendidikan PAUD keluarga termasuk di dalam pendidikan informal. Keluarga adalah tempat anak

belajar pertama kali mengenai dunia sekitarnya, termasuk mengenai bahasa. Pengajaran bahasa pertama kali diperoleh anak di dalam keluarga. Kelurga mengajarkan bahasa dalam percakapan sehari-hari baik itu bahasa ibu (bahasa daerah) dan bahasa Indonesia. Akan tetapi seiring dengan perkembangan zaman makin banyak orang tua yang mulai kehilangan identitas dalam berbahasa khususnya bahasa daerah. Banyak orang tua yang tidak lagi mengajarkan bahasa daerah kepada anak-anaknya sehingga yang anak pahami adalah bahasa Indonesia dalam percakapan sehari-hari. Ketika si anak ditanyakan mengenai bahasa daerahnya, anak tidak dapat menggunakan bahasa daerah dalam percakapannya karena dalam lingkungan terdekatnya yaitu dalam keluarga bahasa yang digunakan adalah bahasa Indonesia.

Pengenalan mengenai bahasa daerah kepada anak penting diberikan sejak usia dini karena pada tahap ini anak mempunyai daya kognitif yang baik. Anak akan mudah menerima bahasa yang diberikan kepadanya melalui percakapan sehari-hari yang dilakukan di rumah. Berdasarkan dari temuan neurosain mengungkapkan bahwa ketika anak berusia 3 tahun, sel otak telah membentuk sekitar $\quad 1.000$ triliun jaringan koneksi/sinapsis. Jumlah ini dua kali lipat lebih banyak dari yang dimiliki orang dewasa. Sebuah sel otak dapat berhubungan dengan 15.000 sel lain. Sinaps-sinaps yang jarang digunakan akan mati, sedangkan yang sering digunakan akan semakin kuat dan permanen. Setiap 
ransangan atau stimulasi yang diterima anak akan melahirkan sambungan baru atau memperkuat sambungan yang sudah ada. Semakin banyaknya dan semakin kuatnya sinaps-sinaps tersebut akan menjadikan otak berfungsi optimal yang berguna bagi perkembangan sensori anak. Komplesitas kuatnya jaringan sel otak anak secara otomatis akan memacu aspekaspek perkembangan seperti kognitif, sosia-emosional, kreativitas bahasa dan lain sebagainya (Novan Ardy Wiyani, 2016: 7). Berdasarkan hal tersebut maka penting peran orang tua dalam memberikan stimulus dalam perkembangan bahasa anak sehingga anak dapat mengembangkan kemampuannya dalam berbahasa khususnya kosakata bahasa daerah.

Berdasarkan dari hasil observasi dan wawancara yang dilakukan kepada guruguru dan siswa-siswi yang berada di TK Buah Rindang tampak bahwa kemampuan berbahasa siswa-siswi yang ada di TK Buah Rindang berkaitan dengan bahasa Dayak Desa sebagai bahasa pertama di dalam keluarga terlihat masih kurang karena anak-anak lebih banyak menggunakan bahasa Indonesia dalam kehidupan sehari-hari dan sangat jarang yang mengetahui bahasa ibu yaitu bahasa daerah mereka khususnya bahasa Dayak Desa. Berdasarkan hal tersebut maka untuk menumbuhkan kembali rasa mencintai bahasa daerah maka diperkenalkan bahasa Dayak Desa melalui kosakata nama-nama binatang dengan menggunakan media flashcard. Melalui media flashcard ini maka diharapkan dapat menambah kosakata bahasa Dayak Desa sehingga pelestarian bahasa Dayak Desa dapat dilakukan sejak usia dini khususnya mulai dari Taman Kanak-Kanak.

Bahasa adalah suatu bentuk komunikasi-entah itu lisan, tertulis atau isyarat yang berdasarkan pada suatu sistem dari simbol-simbol. Bahasa terdiri dari kata-kata yang digunakan oleh masyarakat beserta aturan-aturan untuk menyusun berbagai variasi dan mengkombinasikannya (Santrock, 2007: 353). Selain itu bahasa adalah sistem komunikasi berdasarkan kata dan tata bahasa dan perkembangan kognitif. Pertumbuhan bahasa mengilustrasikan interaksi dari berbagai aspek perkembangan. Dengan matangnya berbagai struktur fisik yang dibutuhkan untuk menghasilkan suara serta mulai aktifnya koneksi saraf yang dibutuhkan untuk mengasosiasikan suara dan makna (Papalia, Olds dan Feldman, 2009: 241). Jika dihubungkan dengan bahasa untuk anak usia dini maka bahasa adalah perubahan sistem lambang bunyi yang berpengaruh terhadap kemampuan berbicara anak usia dini. Dengan kemampuan berbicaranya itu anak usia dini bisa mengidentifikasi dirinya, serta berinteraksi dan bekerja sama dengan orang lain (Novan Ardi Wiyani, 2014: 97).

Berkaitan dengan bahasa maka terdapat kosakata dalam mengenalkan bahasa pada anak usia dini. Menurut Owens (Papalia, Olds dan Feldman, 2009: 360) pada usia 3 tahun rata-rata anak mengetahui 900 sampai 1000 kata. Pada usia 6 tahun anak biasanya memiliki kosakata ekspresif (yang bisa diucapkan) sekitar 2.600 kata dan memahami sekitar 20.000. Dengan bantuan sekolah formal kosakata pasif dan reseptif anak (kata-kata 
yang bisa ia pahami) akan bertambah empat kali lipat menjadi 80.000 kata ketika ia memasuki SMA. Perluasan kosakata yang pesat ini mungkin terjadi karena pemetaan cepat (fast mapping), yang memungkinkan anak untuk memetik arti kira-kira dari sebuah kata baru setelah mendengarnya sekali dua kali dalam percakapan.

Berdasarkan kurikulun 2013 PAUD, lingkup perkembangan bahasa anak usia dini usia 5-6 tahun dibagi menjadi tiga, dengan tingkat pencapaian perkembangan sebagai berikut :

1. Memahami bahasa

Tingkat pencapaian perkembangan anak :
a. Mengerti beberapa perintah secara bersamaan
b. Mengulang kalimat yang lebih kompleks
c. Memahami aturan dalam suatu permainan
d. Senang dan menghargai bacaan

2. Mengungkapkan Bahasa

Tingkat pencapaian perkembangan anak :

a. Menjawab pertanyaan yang lebih kompleks

b. Menyebutkan kelompok gambar yang memiliki bunyi yang sama

c. Menyusun kalimat sederhana dalam struktur lengkap (pokok kalimat-predikit-keterangan)

d. Memiliki lebih banyak kata-kata untuk mengekspresikan ide pada orang lain

e. Melanjutkan cerita/dongeng yang telah diperdengarkan.
Tingkat pencapaian perkembangan anak :

a. Menyebutkan simbol-simbol huruf yang dikenal

b. Mengenal suatu huruf awal dari nama benda-benda yang ada disekitarnya

c. Memahami hubungan antara bunyi dan bentuk huruf

Pengajaran bahasa pada anak lebih mudah dengan menggunakan media karena melalui media anak dapat lebih cepat menangkap pembelajaran yang diberikan oleh gurunya. Media merupakan alat yang memungkinkan siswa untuk mengerti dan memahami sesuatu dengan mudah untuk mengingatnya dalam waktu yang lama dibandingkan dengan penyampaian materi pelajaran dengan cara tatap muka dan ceramah tanpa alat bantu atau media pembelajaran (Rusman, 2017: 216). Penggunaan media dalam kegiatan pendidikan untuk anak usai dini pada umumnya untuk menyampaikan bagian tertentu dari kegiatan pembelajaran, memberikan penguatan motivasi (Sri Mukatiatun, 2016: 83). Berdasarkan hal tersebut maka dapat ditarik kesimpulan bahwa media adalah alat yang dapat membantu anak usia dini dalam proses pembelajaran sehingga anak usia dini dapat memperoleh penguatan dan motivasi dalam pembelajaran.

Secara umum, menurut Rusman (2017: 228-230) ada tiga kelompok dalam media pembelajaran, yaitu:

1. Media Visual adalah media yang hanya dapat dilihat dengan menggunakan indra penglihatan. Misalnya guru menjelaskan dengan

3. Keaksaraan 
menggunakan beberapa media gambar mati atau bergerak.

2. Media Audio adalah media yang hanya dapat didengar dengan menggunakan indra pendengaran saja.

3. Media Audiovisual adalah alat bantu yang dapat digunakan melalui pendengaran dan penglihatan.

Berdasarkan dari tiga kelompok media pembelajaran tersebut maka fokus dalam penelitian ini untuk meningkatkan kosakata anak dalam berbahasa adalah dengan menggunakan media visual yaitu flashcard. Nurjanah (2014: 292) mengemukakan bahwa flashcard merupakan kartu yang berisikan kata atau gambar. Media flashcard dapat digunakan untuk pengembangan perbendaharaan kata pada aspek perkembangan bahasa. Kartu ini dimainkan dengan cara diperlihatkan kepada anak dan dibacakan secara cepat. Menurut Zulkarnaini dan Yeni Idayanti (2016: 54) adapun manfaat dari media pembelajaran flashcard antara lain:

1. Meningkatkan kemampuan anak dalam menghafal dan menguasai huruf dalam waktu cepat.

2. Memudahkan orang tua atau guru dalam mengajar dan mengenalkan huruf kepada anak sejak dini.

3. Anak akan mendapat dua manfaat sekaligus yaitu mengerti bahasa dan mengenal jenis-jenis benda, binatang, buah,dan lain-lain.

Menurut Zulkarnaini dan Yeni Idayanti (2016: 54-55), langkah-langkah penggunaan media kartu huruf bergambar adalah sebagai berikut :

1. Sebelum penyajian

a. Mempersiapkan diri.
Guru perlu menguasai bahan pembelajaran dengan baik, memiliki keterampilan untuk menggunakan media tersebut. Jika perlu untuk memperlancar lakukan latihan secara berulang-ulang meski tidak dihadapan siswa.

b. Mempersiap media kartu huruf bergambar.

Sebelum dimulai pembelajaran pastikan jumlahnya cukup, urutannya betul dan perlu tidaknya media untuk membantu.

c. Mempersiapkan tempat.

Posisi penyaji baik atau tidak, bagaimana penerangannya apakah semua siswa dapat melihat dengan jelas dan pastikan di dalam ruangan tidak ada suara yang menggangu.

d. Mempersipkan siswa.

Posisi siswa sebaiknya ditata dengan baik agar semua siswa dapat melihat media kartu huruf bergambar tersebut.

2. Saat penyajian

a. Berdirilah dengan jarak kira-kira 11,5 meter di depan kelas dimana seluruh siswa dapat melihat guru.

b. Siapkan kartu-kartu dari kelompok yang sama, ditumpuk dan dipegang dengan tangan kiri setinggi dada.

c. Setelah memperlihatkan kartu tersebut guru mengucapkan nama jelas gambar yang terdapat dalam kartu tersebut, misal "bintang".

d. Mintalah siswa mengikuti atau mengulang apa yang guru ucapkan.

e. Setelah itu ambil kartu kedua dari kartu yang diurut paling belakang 
kemudian lakukan seperti langkah c dan d.

f. Lakukan secara berurutan sampai dengan kartu terakhir, dengan kecepatan tidak lebih dengan satu detik untuk tiap-tiap gambar dan tulisan yang ditunjukkan.

g. Setelah seluruh kartu selesai, disebutkan satu persatu secara cepat.

h. Berikan kartu-kartu yang telah diterangkan kepada siswa yang duduk di dekat guru.

i. Mintalah agar semua siswa melihat lagi satu persatu, lalu teruskan kepada siswa lain.

j. Setelah kartu-kartu dikembalikan, lanjutkan dengan diskusi kelas sebagai penguatan ingatan.

Berdasarkan dari beberapa pendapat tersebut maka peran media flashcard sangat mendukung dalam proses pembelajaran yang ada di kelas terutama pada anak usia dini sehingga penyampian materi tentang aspek bahasa dapat disampaikan kepada anak-anak dengan lebih menarik. Penelitian dengan mengunakan media flashcard pernah dilaksanakan oleh Dewi Nurhayati Adhani, Nurul Khofifah dan Dewi Yuanita (2016: 109) dengan judul meningkatkan perkembangan bahasa dengan media flashcard pada anak usia dini di Desa Sanan Rejo Kabupeten Malang. Berdasarkan dari hasil penelitian mereka menunjukkan bahwa di TK Al-Hikmah Malang terdapat beberapa anak rentang usia 5-6 tahun yang perkembangan bahasa khususnya fonologi mengalami peningkatan ketika menggunakan media flashcard. Berdasarkan dari hasil penelitian tersebut maka penggunaan media flashcard dirasakan cukup efektif dalam mengajarkan perkembangan kosakata pada anak-anak usia dini.

\section{METODE PENELITIAN}

Pendekatan dalam penelitian menggunakan pendekatan kualitatif. Menurut Bogdan dan Tylor (Moleong, 2014: 4) metodologi kualitatif adalah prosedur penelitian yang menghasilkan data deskriptif berupa kata-kata tertulis atau lisan dari orang-orang dan perilaku yang dapat diamati. Bentuk penelitian ini adalah penelitian tindakan kelas. Menurut Suharsimi Arikunto (2010:58) PTK adalah suatu penelitian yang dilakukan dikelas dengan tujuan memperbaiki/meningkatkan mutu praktik pembelajaran.

Lokasi yang digunakan untuk melaksanakan penelitian ini adalah TK Buah Rindang yang terletak di Desa Umin Jaya Kecamatan Dedai Kabupaten Sintang. Adapun alasan pemilihan TK ini adalah karena TK ini merupakan satu-satunya TK yang ada di Desa Umin Jaya dan TK ini yang berada di tengah-tengah masyarakat Dayak yang kehidupan sehari-harinya menggunakan bahasa Indonesia dalam komunikasi sehari-hari dan mulai jarang terlihat keluarga yang menggunakan bahasa Dayak dalam komunikasi seharihari. Waktu penelitian dilakukan selama 2 bulan yaitu bulan Agustus sampai September 2018.

Subjek dalam penelitian ini adalah anak-anak kelompok B di TK Buah Rindang Desa Umin Jaya Kecamatan Dedai Kabupeten Sintang yang berjumlah 17 orang yang terdiri dari 10 anak laki-laki dan 7 anak perempuan. Teknik 
pengumpulan data dalam penelitian ini menggunakan: observasi, wawancara, tes dan dokumentasi.

Konsep model tindakan yang digunakan adalah model penelitian tindakan yang dikembangkan oleh Kurt Lewin. Konsep pokok penelitian tindakan Model Kurt Lewin terdiri dari empat komponen, yaitu : a) perancangan (planning), b) tindakan (acting), c) pengamatan (observing) dan d) reflektif (reflecting).

Prosedur Penelitian Tindakan Kelas Langkah-langkah dalam penelitian ini sama untuk setiap siklusnya. Penelitian dikatakan berhasil jika sudah mencapai indikator keberhasilan. Setiap siklus dalam penelitian ini terdiri dari empat langkah yaitu pengamatan awal, perencanaan, tindakan observasi dan refleksi. Langkahlangkah pada setiap siklus merupakan dasar untuk pengambilan keputusan untuk menyusun siklus berikutnya. Adapun siklus dalam penelitian ini adalah sebagai berikut:

1. Siklus I

a. Observasi Awal

Kegiatan yang dilaksanakan pada observasi awal, yaitu menentukan lokasi yang akan diteliti. Peneliti mencari masalah pada lokasi penelitian dan menentukan masalah yang akan diteliti, meminta ijin untuk penelitian dan mengurus perijinan. Peneliti mengumpulkan informasi tentang pembelajaran bahasa khususnya kosakata bahasa daerah yaitu bahasa Dayak Desa di TK Buah Rindang Desa Umin Jaya
Kecamatan Dedai Kabupeten Sintang

b. Perencanaan Pelaksanaan Tindakan Perencanaan tindakan dilaksanakan setelah peneliti melakukan observasi awal. Kegiatan yang dilaksanakan pada perencanaan, yaitu peneliti menentukan target kopetensi mendesain metode pembelajaran menggunakan media flashcard untuk setiap siklus., membuat instrumen perkembangan kosakata bahasa Dayak Desa, membuat lembar observasi, membuat RKM dan RKH untuk setiap pertemuan tindakan dalam melaksanakan kegiatan pembelajaran.

c. Pelaksanaan Tindakan

Sebelum melaksanakan tindakan diadakan observasi kemampuan awal tentang kosakata bahasa Dayak Desa yang anak mengerti yang hasilnya akan dibandingkan dengan hasil observasi pada siklus I dan sikus II. Observasi awal ini untuk memperoleh data tentang kosakata bahasa Dayak Desa yang di fahami oleh anak.

Pelaksanaan tindakan dilakukan dalam enam kali tindakan (pembelajaran menggunakan media flashcard) yaitu 3 kali pada siklus I dan 3 kali pada siklus II. Kegiatan yang dilakukan adalah mengidentifikasi tindakan pada saat proses kegiatan pembelajaran dan hasil dari kegiatan pembelajaran.

d. Observasi 
Observasi yang dilakukan menggunakan instrumen observasi yang meliputi indikator yang didesain berdasarkan fokus penelitian. Kemudian peneliti juga menggunakan alat bantu berupa kamera untuk memperoleh data berupa foto dan video untuk kegiatan pembelajara kosakata bahasa Dayak Desa dengan menggunakan media flashcard. Selain itu peneliti dibantu oleh kolaborator yang akan mencatat apa yang dilihat, di dengar, dan diamati selama proses pembelajaran di kelas berlangsung.

e. Reflektif

Refleksi dilakukan dengan menganalisis hasil tindakan perubahan kemampuan kosakata bahasa Dayak Desa yang difahami anak sebelum dilakukan tindakan dan sesudah dilakukan tindakan. Penelitian ini menganalisis cara meningkatkan kosakata bahasa Dayak Desa anak usia 5-6 tahun.

Pada kegiatan reflektif peneliti bersama dengan guru mengevaluasi hasil dari tindakan yang dilakukan pada siklus I dan melakukan revisi serta melihat perubahan kosa kata bahasa Dayak Desa anak apakah terjadi peningkatan. Hasil kegiatan refleksi ini sangat penting untuk dijadikan sebagai pedoman pada perencanaan tindakan siklus ke II.

2. Siklus II

a. Perencanaan

Hasil refleksi siklus I dijadikan acuan untuk membuat program kegiatan pembelajaran berbasis media flashcard pada siklus II. Langkah perencanaan pada siklus II adalah mempersiapkan dan menyediakan sarana yang dibutuhkan, membuat program kegiatan pembelajaran menggunakan media flashcard. Membuat lembar observasi dan wawancara.

b. Tindakan

Melaksanakan kegiatan yang sudah direncanakan.

c. Observasi

Pengamatan pengetahuan anak dalam kegiatan pembelajaran menggunakan instrumen observasi seperti lembar observasi, alat bantu kamera, dan catatan lapangan.

d. Refleksi

Pada tahap akhir refleksi di siklus II yaitu mentabulasikan data dan dilanjutkan dengan analisis persentase berdasarkan data asessmen awal dan asessmen akhir. Peneliti berdiskusi dengan guru kelas dan membuat interpretasi hasil penelitian.

Kriteria keberhasilan dalam penelitian ini dikatakan berhasil manakala kemampuan anak dalam kosakata bahasa Dayak Desa sudah mencapai $81 \%$ dari keseluruhan jumlah anak sebanyak 17 anak di kelas B. Menurut Suharsimi Arikunto (2010: 128) kriteria keberhasilan penelitian adalah sebagai berikut :

Jika memiliki kesesuaian 81-100\% : sangat baik

Jika memiliki kesesuaian 61-80\% : baik

Jika memiliki kesesuaian 41-60\% : cukup

Jika memiliki kesesuaian 21-40\% : kurang 
Jika memiliki kesesuaian 0-20\% : kurang sekali

\section{HASIL DAN PEMBAHASAN}

Penelitian tindakan kelas ini dilaksanakan pada bulan Agustus sampai September 2018 di kelompok B TK Buah Rindang Desa Umin Jaya Kecamatan Dedai Kabupeten Sintang. TK tersebut berada sekitar 2 jam dari Kabupeten Sintang dan dapat ditempuh dengan menggunakan trasportasi pribadi dan trasportasi umum. TK Buah Rindang ini merupakan satu-satunya TK yang ada di Desa Umin Jaya yang terdiri dari 1 kelas TK A dan 1 kelas TK B. Guru-guru yang mengajar di TK Buah Rindang ini berjumlah 5 orang yang terdiri dari 1 kepala TK dan 4 orang guru. Jumlah siswanya adalah 40 orang yang terdiri dari 13 orang siswa TK A dan 17 orang siswa TK B. TK Buah Rindang termasuk dalam kategori TK yang sederhana karena proses pembelajaran dilaksanakan di kantor balai desa karena belum ada gedung sendiri untuk pelaksanaan pembelajarannya. Proses pembelajaran dilaksanakan dalam satu ruangan yang dibagi menjadi dua yaitu TK A menghadap ke arah selatan dan TK B menghadap ke arah barat. Untuk fasilitas yang ada di TK ini termasuk dalam kategori sederhana karena siswasiswi membawa sendiri peralatan belajarnya seperti meja dan alas duduknya dan tidak adanya fasilitas permainan bagi anak-anak yang dapat melatih kemampuan motorik kasarnya seperti alat permainan ayunan dan jungkat jungkit. Selain itu fasilitas pembelajaran lainnya adalah masih kurangnya media dalam pembelajaran bagi anak-anak sehingga anak-anak lebih pada mewarnai dan bernyanyi saja dan media yang digunakan oleh guru dalam pembelajaran masih sangat kurang.

Pada observasi awal yang peneliti lakukan adalah merancang kegiatan yang akan dilakukan anak dalam meningkatkan kemampuan kosakata bahasa Dayak Desa. Aktivitas yang dilakukan adalah mengamati dalam kegiatan pembelajaran kosakata bahasa Dayak Desa dengan menggunakan media flashcard. Sekolah mendukung kegiatan peneilitian ini karena pihak kepala TK dan guru-guru menerima peneliti dengan ramah. Anak-anak terlihat sangat antusias ketika melakukan permainan kosakata bahasa Dayak Desa dengan menggunakan media flashcard.

Perencanaan kegiatan dilakukan setelah peneliti melakukan observasi awal. Kegiatan yang akan dilaksanakan pada perencanaan, yaitu peneliti menentukan target kopetensi, mendesain media pembelajaran untuk setiap siklus, membuat instrumen untuk kosakata bahasa Dayak Desa, membuat lembar observasi, membuat Rencana Kegiatan Harian (RKH) dan Rencana Kegiatan Mingguan (RKM) untuk setiap pertemuan tindakan dalam pelaksanaan kegiatan pembelajaran, membuat jadwal pembelajaran di TK B.

Kegiatan yang dilakukan adalah mengidentifikasi kekuatan dan kelemahan yang terdapat pada saat proses tindakan dan hasil dari kegiatan. Peneliti menata media flashcard dan menjelaskan tentang cara menggunakan media tersebut. Peneliti menjelaskan nama binatang berkaki empat dan berkaki dua dalam bahasa Indonesia 
dan bahasa Dayak Desa. Peneliti menjelaskan cara penggunaan media flashcard dalam meningkatkan kemampuan kosakata bahasa Dayak Desa pada anak-anak TK B.

Berdasarkan dari hasil siklus I ratarata skor presentasi kemampuan kosakata bahasa Dayak Desa sebesar 65,43\% yang artinya berada pada tingkat penguasaan 61-80\% pada kriteria baik. Akan tetapi terdapat beberapa kendala yang dihadapi pada siklus I adalah anak kurang aktif dalam mengikuti kegiatan, anak hanya terfokus pada media flashcard sehingga konsentrasi anak belum terfokus pada pembelajarannya. Waktu yang digunakan untuk menjelaskan kegiatan pembelajaran kurang efisien sehingga waktu diskusi bersama anak menjadi berkurang. Bahasa yang digunakan oleh peneliti terlalu panjang dan materi kurang dapat dimengerti oleh beberapa anak sehingga anak kurang merespon penjelasan dan pertanyaan dari peneliti. Cara mengatasi kendala yang ditemukan pada siklus I adalah peneliti mengadakan pendekatan pada anak dan menjelaskan penggunaan media flashcard dengan menggunakan kata-kata yang sederhana yang lebih mudah dimengerti oleh anak.

Hasil analisis penelitian tindakan pada siklus II meningkat menjadi $84,18 \%$ yang berada pada tingkat penguasaan 80 $89 \%$ pada kriteria sangat baik. Jadi terjadi peningkatan kemampuan kosakata bahasa Dayak Desa dengan bantuan media flashcard sebesar 18,75\%. Pada siklus II ditemukan bahwa secara umum pembelajaran anak sudah sesuai dengan RKH dan RKM yang diberikan dan anak menunjukkan antusias untuk melakukan kegiatan melalui media flashcard karena anak-anak tampak bersemangat ketika menjawab pertanyaan yang diberikan oleh peneliti contohnya ketika peneliti memberikan pertanyaan dan anak memberikan jawaban yang benar, hal ini ditunjukkan dengan cepatnya anak-anak mengacungkan jari tangan untuk menjawab pertanyaan yang diberikan oleh peneliti. Selain itu tampak bahwa peneliti sudah dapat mengatur waktu sebaikbaiknya sehingga anak dapat mengerjakan semua kegiatan dengan tertib.

\section{KESIMPULAN DAN SARAN}

Kesimpulan

Berdasarkan hasil penelitian diketahui bahwa rata-rata kemampuan kosa kata bahasa Dayak Desa pada siklus I diperoleh hasil sebesar 65,43\%. Hal ini membuktikan bahwa kemampuan kosakata bahasa Dayak Desa dengan menggunakan media flashcard masih belum meningkat secara optimal walaupun sudah pada kategori baik. Sedangkan pada siklus II anak mengalami peningkatan yang signifikan dengan hasil sebesar 84,18\% sehingga dengan demikian dapat dikatakan bahwa peningkatan yang dialami anak sudah optimal pada kategori sangat baik.

Saran

Berdasarkan hasil penelitian dan pembahasan maka dapat dikemukakan beberapa saran yaitu hendaknya setiap guru disamping menguasai materi pembelajaran juga harus mempunyai keterampilan dalam menciptakan media pembelajaran yang menarik sehingga anak-anak menjadi tertarik dengan pembelajaran yang disampaikan. Kepada 
pihak sekolah agar memasukkan pembelajaran bahasa daerah dalam kegiatan pembelajaran sehingga anak-anak dapat mengetahui bahasa daerahnya sejak usia dini. Kepada peneliti yang lain agar menggunakan variasi media flashcard yang lebih menarik dan dapat mengembangkan media flashcard untuk meningkatkan aspek perkembangan yang lain pada anak.

\section{DAFTAR PUSTAKA}

Adhani, D.N., Khofifah, Nurul \& Yuanita, Dewi. (2016). Meningkatkan Perkembangan Bahasa dengan Media Flash Card pada Anak Usia Dini di Desa Sanan Rejo Kabupaten Malang. Jurnal PG-PAUD Trunojoyo. Volume 3, Nomor 2.

Arikunto, Suharsimi. (2010). Prosedur Penilaian Suatu Pendekatan Praktik. Jakarta: Renika Cipta.

PERMENDIKNAS, KURIKULUM 2013 PENDIDIKAN ANAK USIA DINI

Wiyani, Novan Ardi. (2014). Psikologi Perkembangan Anak Usia Dini, Panduan bagi Orang Tua dan Pendidik PAUD dalam Memahami serta Mendidik Anak Usia Dini. Yogyakarta: Gava Media.

(2016). Konsep Dasar PAUD. Yogyakarta: Gava Media.
No.146 Tahun 2014.

Mukatiatun Sri. (2016). Meningkatkan Kemampuan Berbahasa Anak Usia Dini Melalui Media Audio Visual. Jurnal Ilmiah PG-PAUD Semarang. Vol.3 No.2.

Moleong, Lexy J. (2014). Metodologi Penelitian Kualitatif. Bandung: PT Remaja Rosdakarya.

Nurjanah. (2014). Peningkatan Kemampuan Penguasaan Kosakata Melalui Kartu Huruf Bergambar Siswa Kelas II SDN 5 Soni. Jurnal Kreatif Tadulako Online. Vol.4. No.8.

Papalia, Olds dan Feldman. (2009). Human Develompment Perkembangan Manusia. Jakarta: Salemba Humanika.

Rusman. (2017). Belajar dan Pembelajaran Berorientasi Standar Proses Pendidikan. Jakarta: Kencana.

Santrock, John W. (2007). Perkembangan Anak, edisi kesembilan, jilid 1. Jakarta: Erlangga.

Undang-Undang Sistem Pendidikan Nasional No. 20 Tahun 2003.

Zulkarnaini dan Idayanti Yeni. (2016). Media Kartu Huruf Begambar Lebih Meningkat Kemampuan Menulis Permulaan pada Siswa Kelas I SD Negeri 1 Gandapura Kabupaten Bireun. JUPENDAS. Vol. 3. No. 1. 